\section{Dendrochronology for the Third Millennium}

\author{
Mendoza, Argentina, 2-7 April, 2000
}

The International Conference on Dendrochronology for theThird Millennium was hosted by the Laboratorio de Dendrocronologia in Mendoza, Argentina, April 2-7, 2000. The meeting attracted 183 scientists from 31 countries. The reports were divided into oral and poster presentations and grouped in the following sessions:

- Biological Basis and General Dendrochronology.

Chair: M. Hughes

- Mathematical and Statistical Methods in Dendrochronology. Chair: E. Cook

- Stables Isotopes in tree-rings. Chairs: G. Schlesser and S. Levitt

- Tree-ring Records of Ocean-Atmospheric Circulation. Chair: D. Sthale

- Modern and Sub-fossil MillennialTree-Ring Records. Chairs: K. Briffa and F. Roig

- Global Change as Evidenced by Tree-Ring Studies. Chair: G. Jacoby

- Tree Ring Research in Tropical Environment. Chair: M. Worbes

- Applications of Dendrochronology to Geomorphology. Chair: G. Wiles

- Using Dendroecology in Forest Dynamics Research.

Chair: M.D. Abrams

- Reconstructing Climate Variability and Changes from Treelines. Chair: B. Luckman

- Dendrochronological Applications in the Southern Hemisphere.

Chairs: J. Boninsegna and R. Villalba

There were a total of 256 presentations at the conference, of which many addressed PAGES-related issues. In particular, the sessions on "Tree-ring Records of Ocean-Atmospheric Circulation", "Modern and Sub-fossil Millennial Tree-Ring Records" and "Global Change as Evidenced by Tree-Ring Studies" were devoted to studies on the reconstructions of past meteorological parameters, past variations of forc- ing factors and on the reconstructed variations of the atmospheric circulation. Noticeable advances were reported in the development of long tree-ring chronologies in the Central Asia region and the Arctic. Also, an important increase in the number of long chronologies worldwide was presented. "Stable isotopes in tree-rings," a somewhat controversial issue, was dealt with principally in terms of methodological aspects and the modeling the isotope contents in the rings to assess the significance of intrannual variations in terms of meteorological parameters.

Tree-ring networks over tropical regions are rather scarce. However extremely encouraging progress was reported during the conference. Many fundamental requirements such as evaluation of growth rates and growth behavior of tropical trees, the anatomical description and proof of the annual nature of tree-rings, the climate-growth relationship and dating procedures in tropical trees were discussed. An analysis of the anatomical structures of African woods and their relation to seasonal climate provides for the first time the potential to obtain climatic information from African tropical trees. Similarly, several reports dealt with trees of tropical Latin America including Amazonia. The presence of visible, cross-datable tree-rings in some regions of tropical Australia was also presented.

One special session was devoted to the studies of tree-line environments. Tree-line research in regions of Siberia, Europe and New Zealand were important contributions to the session. A group of 21 presentations dealt with studies developed along the PEP I transect from Alaska to Tierra del Fuego. These presentations were all communication reports from the Project " Assessment of Present, Past and Future Climate Variability in the Americas from Treeline Environments" which was carried out with the financial support of the Inter-American In-

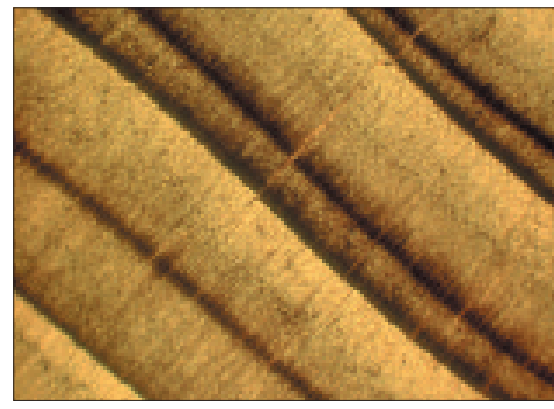

False rings in Mexican Cypress (Cupressus Iusitanica). Photo by Peter Brown.

stitute for Studies of the Global Change (IAI). The primary scientific goal of the ongoing project is to assess climate variability from climate sensitive tree-ring records along the above-mentioned transect. These series will be used to develop long proxy records of temperature and precipitation from which other parameters such as streamflow, drought and atmospheric circulation indices (ENSO, PDO, PNA, the Mexican Monsoon and various Antarctic indices) can be derived.

The reports to this tree-line session included the development of tree-line chronologies from sites ranging from $69^{\circ} \mathrm{N}$ to $55^{\circ} \mathrm{S}$ including the tropics. In Mexico, sampled sites and new species were reported from ca. $17^{\circ} \mathrm{N}$. In the Southern Hemisphere, some reports indicated the results of promising exploratory sampling in subtropical Argentina, Bolivia and Peru. The development of the highest tree-ring chronology in the world from Polylepis tarapacana growing at $4900 \mathrm{~m}$ a.s.I. near Volcan Sajama in Bolivia at $18^{\circ} \mathrm{S}$ and its relations with climate was also presented in this session. This was the first International Conference on Dendrochronology hosted in the Southern Hemisphere. Consequently, a session on the Southern Hemisphere was also presented. There, several presentations accounting on the progress in the development of chronologies, studies on ecology, forest dynamics and new species suitable for dendrochronological studies.

\section{José Armando Boninsegna}

Laboratorio de Dendrocronología,

Mendoza, Argentina

pbonin@lab.cricyt.edu.ar 